\title{
Erratum to: Scalable distributed implementation of a biologically inspired parallel model
}

\author{
Gabriel Ciobanu ${ }^{1}$
}

Published online: 29 February 2016

(C) The Author(s) 2016. This article is published with open access at Springerlink.com

\section{Erratum to: Complex Intell. Syst. DOI 10.1007/s40747-015-0003-3}

When the article was published unfortunately the Creative Commons Attribution (CC-BY) 4.0 license information was missing in the article. This has now been corrected.

The correct copyright line is as follows:

(C) The Author(s) 2016. This article is published with open access at Springerlink.com

The correct license text is as follows:

Open Access This article is distributed under the terms of the Creative Commons Attribution 4.0 International License (http://creativecommons.org/licenses/by/4.0/), which permits unrestricted use, distribution, and reproduction in any medium, provided you give appropriate credit to the original author(s) and the source, provide a link to the Creative Commons license, and indicate if changes were made.

\begin{abstract}
Open Access This article is distributed under the terms of the Creative Commons Attribution 4.0 International License (http://creativecomm ons.org/licenses/by/4.0/), which permits unrestricted use, distribution, and reproduction in any medium, provided you give appropriate credit to the original author(s) and the source, provide a link to the Creative Commons license, and indicate if changes were made.
\end{abstract}

The online version of the original article can be found under doi:10.1007/s40747-015-0003-3.

\footnotetext{
Gabriel Ciobanu

gabriel@info.uaic.ro

1 Romanian Academy, Institute of Computer Science, Iaşi, Romania
} 